\title{
Sosyal Medya Çağında Kuşakların Sosyal Medya Kullanımı ve Değerlerine Yönelik Bir Dizi Ölçek Geliştirme Çalışması
}

\author{
DOI: $10.26466 /$ opus.557240 \\ * \\ Levent Deniz $^{*}$ - Aylin Tutgun-Ünal** \\ * Doç. Dr, Marmara Üniversitesi, Atatürk Eğitim Fakültesi, İstanbul / Türkiye \\ E-Posta: ldeniz@marmara.edu.tr \\ ORCID: $\quad$ 0000-0002-5786-215X \\ ** Dr. Öğretim Üyesi, Üsküdar Üniversitesi, İletişim Fakültesi, İstanbul/ Türkiye \\ E-Posta: aylin.tutgununal@uskudar.edu.tr \\ ORCID: $\quad$ 0000-0003-2430-6322
}

\section{Öz}

Bu araştırmada sosyal medya kullanımın her geçen gün hızla yayıldığı toplumda yer alan farklı kuşakların değişen değer ve davranışlarının belirlenebilmesi amacıyla bir dizi ölçek geliştirmek amaçlanmıştır. Araştırmanın çalışma grubunu Baby Boomers kuşağı (1944-1964) ile Z kuşă̆̆ (2000-2020) arasında yer alan 516 kişi oluşturmuştur. Ölçeklerin geliştirilme aşamalarında yapı geçerliğinin sağlanması için açımlayıcı faktör analizi ve güvenilirliğinin sağlanması için ise Cronbach Alfa iç tutarlılık katsayıları kullanılmıştır. Yapılan geçerlilik ve güvenilirlik çalışmaları sonucunda üç bağımsız ölçek elde edilmişstir. Bu ölçekler Sosyal Medya Kullanımı Ölçeği, Çalışma Hayatı Ölçeği ve Farklılıkları Kabul Ölçeği olarak adlandırılmışlardır. Sosyal Medya Kullanımı Ölçeği, Süreklilik ve Yetkinlik adını alan iki alt ölçeğe sahiptir. Çalışma Hayatı Ölçeği, Işe Önem Verme ve Kurallara Uyma adını alan iki alt ölçeğe sahiptir. Farklılıkları Kabul Ölçeği ise Farklı Dini/Etnik Yapıları Kabul, Farklı Dış Görünüşleri Kabul ve Farklı Düşünceleri/Değerleri Kabul adını alan üç alt ölçeğe sahiptir. Tüm ölçek ve alt ölçekler geçerli ve güvenilir bulunmuştur. Elde edilen ölçeklerin araştırmacılar tarafından bağımsız olarak tek tek veya bir batarya olarak birlikte kullanilması umulmaktadır.

Anahtar Kelimeler: Sosyal medya, Kuşaklar, Değerler, Sosyal medya kullanımı, Ölçek geliştirme 


\title{
Development of a Set of Scales toward the Use of Social Media and Values of Generations in Social Media Age
}

\begin{abstract}
The main aim of this research is to develop a set of scales to measure the values and behaviors of different generations in the society where the use of social media spreading rapidly day by day. The participants of the research consisted of 516 people from generation Baby Boomers (1944-1964) to generation Z (2000-2020). Exploratory factor anaylsis was used for the structure validity and Cronbach's Alpha coefficient was calculated for the internal reliability through the development phases of the scales. The validity and reliability studies revealed three independent scales. The scales were named as Social Media Usage Scale, Work Life Scale and Acceptance of Diversity Scale. Social Media Usage Scale has two sub scales naming as Continuity and Competence. Work Life has two sub scales naming as Giving Importance to Work and Obeying the Rules. Acceptance of Diversity Scale has three sub scales naming as Acceptance of Diverse Religions/Ethnicities, Acceptance of Diverse Appearances and Acceptance of Diverse Ideas/Values. All these scales and sub scales are found to be valid and reliable. It is expected that the scales will be used independently or as a battery in whole by the researchers.
\end{abstract}

Keywords: Social media, Generations, Values, Social media usage, Scale development 


\section{Giriş}

Hayatın her alanında farklı davranışlar ile kuşatılmaktayız. Gerek aynı yaşta olsun gerekse farklı yaşlardaki her bireyin kendine ait değerleri ve davranışları vardır. Değerler, kişilerin davranış biçimine rehberlik ederek insanları ve olayları değerlendirmemizi sağlayan, bir davranışın altında yatan nedenleri açıklamamıza yardımcı olan kavramlardır (Morsümbül, 2014). Bu bağlamda genellikle yaş özelliği göz önünde bulundurularak bireylerin belirli zaman dilimlerine ayrılmasıyla değer ve davranışlarının farklılaşması kuşak kavramı doğrultusunda açıklanmaktadır. Diğer taraftan kuşaklar gruplandırılarak incelenirken yaş ile birlikte belirli bir zaman dilimindeki olaylar bütününün ve teknolojik gelişmelerin de bu gruplandırmada ön plana çıktığı gözlenmektedir.

Kuşak kavramının nasıl ortaya çıtığı incelendiğinde, ilk olarak Auguste Comte (1974) tarafından bilimsel olarak ele alındığı ve kuşakların tarih sürecinde hareket eden kuvvetler olarak görüldüğü ortaya çıkmaktadır. Buna göre, toplumsal ilerleme ancak bir kuşağın bir sonraki kuşağa aktaracağı birikimler ile sağlanacaktır. Karl Mannheim ise, yirminci yüzyılda sosyal bilimlerdeki araştırma yöntemlerini kuşak araştırmalarında ilk defa kullanarak kapsamlı ve sistematik araştırmalar yapmıştır. Böylece, kuşak kavramını ortak alışkanlıkları, kültürü ve zaman dilimini paylaşan insanlar topluluğu olarak tanımlayarak, sadece sosyal etkileşim olarak değil ayn zaman diliminde yaşamanın ve duruma uygun davranış sergileme eğiliminin de anlamlı bütünlük oluşturmada etkili olduğunu belirtmiştir (Mannheim, 1950, 1952). Bununla birlikte, bir bireyin özellikle gençlik yıllarında meydana gelmiş olan sosyal, politik, ekonomik olayların o bireyin değerler sisteminin oluşmasında etkili olduğu ve yaşamı boyunca değişmeyip sabit kaldığı belirtilmektedir (Hung ve diğerleri, 2007; Strauss ve Howe, 1991).

Türkiye'de kuşak konusundaki çalışmaların daha çok 2000'li yıllarda yapıldığı ve kuşak kavramının alandaki kuramsal ve uygulamalı araştırmalara dayanılarak çeşitli şekillerde tanımlandığı söylenebilir. Genel olarak ele alınırsa kuşak kavramının, dünya genelindeki ekonomik ve sosyal hareketlerle oluşmuş zaman aralıklarından doğduğu (Berkup, 2014; Latif 
ve Serbest, 2014), ve ebeveynlerle çocuklarının doğumları arasındaki ortalama zaman aralığı olduğu (McCrindle ve Wolfinger, 2010, s.8-13) şeklinde ifade edildiği anlaşılmaktadır.

Dünya genelinde kuşaklar çeşitli adlandırmalarla gruplandırılarak incelenmektedir. Bu gruplamalarda yaygın olarak kuşaklar, Sessiz Kuşak (1927-1945), Baby Boomer (1946-1964), X Kuşağı (1965-1979), Y Kuşağ1 (1980-1999) ve Z Kuşağı (2000 ve sonrası) olarak adlandırılmaktadır (Berkup, 2014; Dewanti ve Indrajit, 2018; Toruntay, 2011; Tutgun-Ünal, 2013). Ancak diğer yandan alanyazındaki kuşak terminolojisi incelendiğinde adlandırılmalarda ve tarih aralıklarında farklılıklar görülebilmektedir. Örneğin, Sessiz Kuşak yerine "Gelenekçiler", "Bunalım Bebekleri”, "Yetişkinler" (Berkup, 2014; Ekşili ve Antalyalı, 2017), Baby Boomer yerine “Bebek Patlaması" (Census, 2006, s.2; Johnson ve Johnson, 2010, s.7; TutgunÜnal, 2013; Zemke vd., 2013, s.24;), X Kuşağı yerine “Bebek Düşüşü (Baby Bust)" (Zemke vd., 2013, s.89), Y kuşağı yerine “Milenyum Kuşağı", “Dijital Kuşak", "www Kuşağı", "Neden Kuşağı (Gen Why)", "Sonrakiler (Nexters)", "Eko patlaması (Echo Boomers)", "2000 kuşağ1" (Gravett, 2007, s.44; Johnson ve Johnson, 2010, s.102; Latif ve Serbest, 2014; Lower, 2008, s.81; Tolbize, 2008, s.5-6; Toruntay, 2011; Türk, 2013, s.9), Z kuşağ1 yerine İGen (Taş, Demirdöğmez ve Küçükoğlu, 2017) gibi kavramlardan söz edilmektedir.

Kuşaklararası iletişim, içinde bulunulan toplumsal yapı ve ortamlar (aile, okul, işyeri vs.) ele alınarak farklı alanlarda çalışan araştırmacılar tarafından farklı boyutlarıyla incelemelere konu olmuştur. Kuşaklararası iletişim, işletme, tıp, sosyoloji, klinik psikoloji, eğitim gibi pek çok alanda ele alınmaktadır (Akdemir ve diğerleri, 2013; Alwin ve Mccammon, 2007; Biggs, 2007; Ekşili ve Antalyalı, 2016; Latif ve Serbest, 2014; Tutgun Ünal, 2013; Tutgun-Ünal ve Soykan, 2015; Yıldırım ve Becerikli, 2013). Geçmişten bu yana kuşaklararası çatışma konusu sosyoloji, psikoloji ve pedagoji alanları üzerinden ele alınmakta olup, çalışmalarda kuşaklararası iletişim farklılıkları ortaya koyulmaktadır (Ayçiçek, 1994; Mannheim, 1952, s.163; Sarıtaş ve Barutçu, 2016; Tutgun-Ünal, 2013).

Araştırmalarda, kuşakların bir konuya yönelik alışkanlıklarının da kendi içinde çeşitlendiği görülmektedir. Örneğin, tüketicilerin karar verme alışkanlıklarının incelendiği bir araştırmada (Engizek ve Şekerkaya, 2016) X ve Y Kuşağı kadınlarının alışveriş yapma alışkanlıkları ve 
farklılıkları olduğu belirlenmiştir. Yine elektronik ticarette $X, Y, Z$ kuşaklarının tüketici davranışlarının otaya konmaya çalışıldığg bir tarama çalışmada da, örneğin $X$ kuşağından olan bir hizmet/mal sağlayıcının $Y$ ve $Z$ kuşağındaki tüketici kitlesinin farklılıklarını anlaması ve dikkate alması gerektiği vurgulanarak (Dewanti ve Indrajit, 2018) kuşaklar arası farklılıkların önemine dikkat çekilmektedir. Satın alma davranışları bağlamında kuşaklar arası karşılaştırmalar yapan araştırmaların yanı sıra tek bir kuşağın yönelimlerini inceleyip anlamaya çalışan araştırmalar (Onurlubaş ve Öztürk, 2018) da bulunmaktadır.

Teknolojinin hızla ilerlemesiyle birlikte kuşakların iletişim araçlarıyla etkileşimlerinin konu alındığı güncel araştırmalar, özellikle teknolojiyle küçük yaştan beri iç içe olanlar ile sonradan tanışan kuşaklar arasındaki farklılıkların tespit edilmesi yönüne kaymıştır. Araştırmalarda önceleri gazete, radyo, televizyon gibi kitle iletişim araçları ile insanların ilişkisi incelenirken (Pecchioni, Wright ve Nussbaum, 2005; Williams, 2001; Williams ve Harwood, 2008), şimdilerde WEB 2.0 teknolojilerinin hızla yaygın hale gelmesiyle farklı kuşakların bilgisayar, internet, cep telefonu ve özellikle de sosyal medya ile ilişkisi incelenmektedir (Asmafiliz ve Şalvarc1 Türeli, 2018; Dyke, Haynes ve Ferguson, 2007; Kuyucu, 2017; Özdemir, 2017; Sağır ve Eraslan, 2019; Süer, Sezgin ve Oral, 2017; Tutgun-Ünal, 2013, 2015; Tutgun-Ünal ve Soykan, 2015).

Günlük yaşantıda hayatımızın pek çok alanında bulunduğumuz ortamların farklı yaş gruplarını barındırması beraberinde iletişimsel sorunları da ortaya çıarmaktadır. Araştırmaların, çeşitli yaş gruplarından oluşan iş yeri ortamlarındaki kuşaklararası iletişime yoğunlaştığı da görülmektedir (Berkup, 2014; Çetin Aydın ve Başol, 2014; Latif ve Serbest, 2014; Macky, Gardner ve Forsthy, 2008; Martin ve Tulgan, 2002; Toruntay, 2011; Yiğit, 2010). Bir çalışmada, iş yerlerinde yaşanan sorunların önemli bir kısmının kuşaklararası algı, yöntem, uygulama ve iletişim farklılıkları olduğu belirtilmektedir (Latif ve Serbest, 2014). Martin ve Tulgan (2002), aynı örgütte çalışan $X$ ve $Y$ kuşaklarının iletişimsel sorunlarının olabileceğini, örgüt yönetiminin bu sorunları aşmak için çalışanlara yardımcı olması gerektiğini vurgulamaktadır. Buradan hareketle, sözü edilen iki kuşağın iletişim kurabilmesi için mesai saatleri dışında informal faaliyetlerde birlikte bulunmaları gerektiği belirtilmektedir. Kuşaklararası iletişi- 
min konu alındığı diğer bir çalışmada da dünya genelinde yaşlı nüfus artışının iletişim sorunlarını da beraberinde getirdiğini vurgulamaktadır (Yıldırım Becerikli, 2013). Araştırmaların $X$ ve $Y$ kuşaklarının iş yaşamı algılarına ve liderlik özelliklerine de yoğunlaştığı görülmektedir (Akdemir ve diğerleri, 2013; Aydemir ve Dinç, 2015; Demirkaya ve diğerleri, 2015; Kelgökmen İlic ve Yalçın, 2017). Diğer taraftan da henüz iş yaşamına katılmayan $\mathrm{Z}$ kuşağının ileriye dönük çalışma yaşamı alışkanlıklarının ve muhtemel etkilerinin tamamen farklı olacağı varsayılarak yapılmış araştırmalar bulunmaktadır (İnce, 2018; Taş, Demirdöğmez ve Küçükoğlu, 2017).

Araştırmalarda gerek çalışma ve iş değerleri gerekse diğer değer sistemleri (kültürel, toplumsal, bireysel) farklı seviyelerde incelenmiş olup değerlerin bireysel tutumları ve bilişsel süreçleri etkilediği ortaya koyulmuştur (Hofstede, 1984, s.21-22; Inglehart, 2008, s.7-12; Rokeach, 1973; Rokeach and Ball-Rokeach, 1989, s.775; Schwartz, 2006, s.139). Makro düzeyde bütüncül olarak değerlerin çalışılması kültürel örüntüleri yansıttığı için oldukça önemlidir. Fakat mikro düzeyde ise bireylerin doğum tarihlerine göre kuşak adlandırmaları ile gruplanarak, o gruba ait değerlerin tespit edilmesine yönelik çalışmaların yapılması, incelemelerin detaylandırılması sözü edilen kuşakların daha iyi anlaşılmasına olanak sağlamaktadir.

Y kuşağı, kuşaklararası farklılıkların en belirgin hissedildiği kuşaktır. Z kuşağı da göz önüne alındığında, bu kuşakları diğer kuşaklardan ayıran en önemli özelliğin bilişim teknolojileri ve sosyal medyanın yaygın olarak kullanıldığı bir zaman diliminde dünyaya gelmeleri olduğu söylenebilir. Türkiye İstatistik Kurumu (TÜİK) verilerine göre, Z kuşağında olan ve 2000 sonrasında doğan 15-19 yaş aralığındaki gençlerin toplam nüfusa oranının yaklaşık \%13; Y kuşağında olan ve 1980 sonrasında doğan 20-39 yaş arasındaki kuşağın toplam nüfusa oranının ise yaklaşı $\% 32$ 'ye ulaştığ1 anlaşılmaktadır (TÜİK, 2018). Y ve Z kuşağının toplamında \%45'e ulaşan bu yüksek oran pek çok araştırmacıyı kuşaklar arası çalışmaya yönlendirmiştir.

Araştırmacılar yaptıkları araştırmalarla (Akdemir ve diğerleri, 2013; Ekşili ve Antalyalı, 2017; İnce, 2018; Latif ve Serbest, 2014; Mücevher, 2015; Taş, Demirdöğmez ve Küçükoğlu, 2017; Tutgun-Ünal, 2013) Y ve Z kuşak- 
larının iş, aile, eğitim gibi alanlardaki yaşantıları, beklentileri gibi konulardaki farklılıkları anlamayı ve ortaya koymayı amaçlamışlardır. Diğer yandan yapılan araştırmalar farklılıklar kadar kuşaklararası benzerliklerin de olduğunu, dolayısıyla kuşakların bu yönüyle de ele alınması gerektiği vurgulamışlardır (Ekşili ve Antalyalı, 2017; Toruntay, 2011; TutgunÜnal, 2013).

Alandaki çalışmaların genellikle, daha çok ilgi odağı olması sebebiyle ve ayrıca ulaşılması ve veri toplaması daha kolay olduğu için $X$ ve $Y$ kuşakları üzerinde yoğunlaştığı anlaşılmaktadır. Bu kuşakların özelliklerinin ortaya konulmasında ve birbirleriyle karşılaştırılmalarında çeşitli ölçeklerin (veri toplama araçlarının) kullanıldığı anlaşılmaktadır. Kuşaklar arası özelliklerin incelendiği araştırmalarda, bu özellikleri ortaya koyacak ölçeklerin geliştirilmesi ayrı bir önem kazanmıştır. Var olan çeşitli genel amaçlı ölçekleri kullanmak mümkün olsa bile ortaya çıkan yeni değerler, davranışlar doğal olarak araştırmacıları amaca uygun yeni veri toplama araçları geliştirmeye veya uyarlamaya da yöneltmiştir. Dolayısıyla kuşaklar arası farklılık ve benzerliklerin belirlenmesinde hem amaca özel geliştirilmiş hem de genel amaçlı ölçeklerin kullanıldığı görülmektedir. Örneğin, Y kuşağının özelliklerini belirlemeye yönelik bir araştırmada, araştırmacıların geliştirdiği “Türkiye'de Y Kuşağı Algısı Ölçeği”nin kullanıldı̆̆ görülmüştür (Ekşili ve Antalyalı, 2017). Ölçek 4 boyuttan oluşmakta olup bu boyutlar "Teknoloji Kullanımı", "Depresif Benmerkezcilik", "Proaktiflik" ve "Sosyallik" olarak adlandırılmıştır. Bir lisede okul yöneticileri ile yürütülen bu araştırma sonucunda, yöneticilerin $Y$ kuşağını yoğun teknoloji kullanan, orta düzeyde proaktif, yüksek düzeyde depresif benmerkezci olmakla birlikte yüksek düzeyde sosyal bir yapıya sahip bireyler olarak algıladıkları ortaya çıkmıştır.

Y kuşağı üniversite öğrencilerinin X kuşağı akademisyenler tarafından nasıl algılandığına yönelik olarak yapılan bir çalışmada ise, Smith ve Smith"1 (2005) tarafından geliştirilen “Öğretmenlerin Y Kuşağı Öğrenci Özellikleri Algıları Ölçeği” kullanılmıştır. Bu ölçeğin araştırmacı tarafından Türkçe'ye çevrilmiş versiyonu "İş yönelimli", "İletişim Yönelimli" ve

\footnotetext{
${ }^{1}$ Smith, V. W. ve Smith, M. O., (2005), Analysis of Generation Y: Teachers' Perceptions, Journal of Business and Training Education, Vol: 14, p. 21-29. (Mücevher, 2015'den alıntı).
} 
“Öğrenme Yönelimli” olarak üç boyuttan oluşmaktadır. Boyutların altında "İşbirliği yapabilirler ve başkalarıyla iyi çalışabilirler", "Diğerlerine sayg1 gösterirler", "İyimserdirler", "Yeni teknolojiye ilgi duyarlar" gibi toplam 43 ifade yer almaktadır. Aynı çalışmada, Y kuşağı üniversite öğrencilerinin $X$ kuşağ 1 akademisyenlerin kendileri ile olan etkileşimleri hakkındaki algı ve görüşleri de Wubbels ve Levy²'nin (1993) geliştirdiği ve Şimşeker ${ }^{3}$ in de (2015) 64 maddelik versiyonunu çalışmasında kullandığı "Öğretmen Etkileşim Ölçeği" ile ölçülmüştür. Bu ölçekte, 64 madde ve sekiz boyut vardır. Bu boyutlar "Liderlik", "Yardımsever/Canayakın", "Anlayışlı", "Özgürlükçü", "Kararsız", "Memnun Olmayan”, "Uyarıcı” ve "Sert" olarak adlandırılmaktadır (Mücevher, 2015).

Diğer taraftan, Y kuşağının kariyer algısı ve kariyer değişimini ölçmeye yönelik olarak Akdemir ve diğerleri (2013) tarafından iki boyuttan oluşan bir ölçme aracı geliştirilmiştir. 15 maddeden oluşan ölçekte, "Daha iyi bir pozisyon teklifi aldığımda şuan çalıştığım işimi değiştirebilirim", "Çalıştığım işim kendi eğitimim ile ilgili olmalıdır", "Rekabet benim için kendimi geliştirme fırsatıdır", "Yapmam söylenen işin neden yapmam gerektiği de söylenmelidir/ sorarım" gibi ifadeler yer almaktadır. Araştırmada Y kuşağının kariyer algısı ve kariyer değişimi boyutlarının demografik özelliklerine göre farklılaşması incelenmiş olup kadınların kariyer algısı ve kariyer bırakma eğiliminin erkeklere göre anlamlı düzeyde yüksek olduğu bulunmuştur. Aynı araştırmada Y kuşağının liderlik özellikleri de araştırılmıştır.

Kuşakların iş-yaşam dengesi ve çalışma değerleri arasındaki farklılıkları belirlemeye yönelik bir çalışmada, Daniels ve McCarraher ${ }^{4}$ (2000) tarafından geliştirilen ve 10 sorudan oluşan "İ̧̧-yaşam dengesi ölçeği" kullanılmıştır. Ölçekte "Stres ve ilişkiler" ile "Yoğun çalışma" olarak adlandırılan iki boyut vardır. Çalışma değerlerini ölçebilmek için de Blau ve

\footnotetext{
${ }^{2}$ Wubbels, Th., Creton, H. A., Levy, J., \& Hooymayers, H. P. (1993). The model for interpersonal teacher behaviour, In Th. Wubbels \& J. Levy (Eds.), Do you know what you look like? Interpersonal relationships in education (p.13-28). London: The Falmer Press. (Mücevher, 2015'den alıntı).

${ }^{3}$ Şimşeker, M., (2005), Sekizinci Sınıf Öğrencilerinin Matematik Öğretmenlerinin Kişiler-Arası Davranış Özelliklerini Algılamaları, Orta Doğu Teknik Üniversitesi Fen Bilimleri Enstitüsü, Orta Öğretim Fen ve Matematik Alanları Eğitimi Bölümü Yüksek Lisans Tezi, Ankara. (Mücevher, 2015'den alıntı).

${ }^{4}$ Daniels, L. ve McCarraher, L. (2000), The Work-Life Manual. Industrial Society, London. (Aydemir ve Dinç, 2015'den alıntı).
} 
Ryan $^{5}$ (1997) tarafından geliştirilen 12 soruluk PWE isimli bir ölçek kullanılmıştır. Ölçek "Sıkı Çalışma”, "Boş vakitten hoşlanmama”, "Çilecilik" ve "Bağımsızlık" isimli dört boyuttan oluşmaktadır. Her iki ölçeğin de yedili likert tipinde olduğu belirtilen araştırma sonucunda, $X$ ve $Y$ Kuşağının Gelenekçi Kuşağa ve Bebek Patlaması Kuşağına göre daha iyi bir iş-yaşam dengesine sahip olduğunu bulunmuştur. Pek çok sonuca ulaşılan araştırmada, Gelenekçi ve Bebek Patlaması Kuşaklarının sıkı çalışma özelliklerinden bir şey kaybetmediği belirtilmektedir (Aydemir ve Dinç, 2015).

Kuşakların değer ölçümüne yönelik bir araştırmada da Schwartz'ın $\left(1992^{6}, 1994^{7}\right)$ değer yaklaşımından yola çıkılmış, "Değişime Açıklık", "Muhafazakârlık", "Kendini Güçlendirme", "Kendini Aşma" temel değerleri açısından kuşaklar karşılaştırılmıştır. Schwartz tarafından geliştirilen ve kişisel değerleri ortaya çıkaran 6 ' 1 l derecelendirilmiş Likert türündeki 21 maddelik kültürel değerler ölçeğinde her bir ifadeye kişinin ne derece benzediği sorulmuştur. Kuşaklararası kültürel değerlerin üç kuşak arasındaki değişiminin Ankara örnekleminde sorgulandığı araştırma sonucunda, kuşaklararasındaki değer değişiminin hızlı olmadığı ancak uzun vadede büyük değişimlerin gerçekleşebileceği belirlenmiştir. Aynı zamanda, kuşaklararası farklılıkların bilinip ona göre davranılmasının sosyal sorunları çözebileceği vurgulanmıştır (Morsümbül, 2014).

Börü ve Yurtkoru (2016) ise, iş yaşamındaki Y kuşağ çalışanlarının iş yaşam tarzlarını anlayabilmek amacıyla 42 maddelik "İş Yaşam Tarzı Ölçeği" geliştirmiştir. Ölçme aracı beşli Likert türünde olup 15 boyuttan oluşmaktadır. Boyutlar "Sabit çalışma saatleri, "Daha iyi iş/pozisyon arayışı", "Hırslı olmama ve rekabetten/riskten kaçınma", "Giyim kuralları", "İş esnekliği", "İşi sorgulama", "Sosyalleşme", "Yurtdışı kariyer olanağı", "Eğitim desteği", "İş-eğitim uyumu", "İşyeri uzaklı̆̆ı", "Evden çalışma olanağı", "Sosyal medya kullanımı", "Hareketli bir iş" ve "Girişimcilik" olarak yer almaktadır. Ölçek X kuşağı için de uygun hale getirilmiş olup her iki kuşağa uygulanmıştır. Araştırmada, Y kuşağının sosyalleşmeye,

\footnotetext{
${ }^{5}$ Blau, G., ve Ryan, J. (1997), 'On Measuring Work Ethic: A Neglected Work Commitment Facet', Journal of Vocational Behavior, 51, pp.435-448. (Aydemir ve Dinç, 2015'den alıntı).

${ }^{6}$ Schwartz, S. H. (1992). Universals in the Content and Structure of Values: Theoretical Advances and Empirical Tests in 20 Countries. (M. Zanna, Ed.), Advances inExperimental Social Psychology in (pp. 1-65). New York: Academic Press. (Morsümbül, 2014'den alıntı).

${ }^{7}$ Schwartz, S. H. (1994). Are the Universal Aspects in the Structure and Content of Human Values. Journal for Social Issues, 50(4), 19-45. (Morsümbül, 2014'den alıntı).
} 
sosyal medya kullanımına, iş yerinde eğitim ve evden çalışma olanaklarına daha önem verdiği bulunmuştur.

Diğer bir ölçme aracı ise, personel bulma ve seçme süreçlerinde sosyal medya kullanım yatkınlığının kuşaklararasında farklılık gösterip göstermediğini tespit edebilmek için Erdal (2018) tarafından geliştirilmiştir. Araştırmacının geliştirdiği üçlü Likert türündeki ölçme aracı kendi içinde üç ayrı ölçekten oluşmaktadır. Birinci ölçek 9 sorudan oluşmakta olup katılımcıların personel bulma süreçlerinde sosyal medyayı kullanım yatkınlığını; 10 soruluk ikinci ölçek, katılımcıların personel seçme süreçlerinde sosyal medya kullanım yatkınlığını; 5 sorudan oluşan üçüncü ölçek ise (devamına bir soru da çoktan seçmeli olarak eklenmiştir) katılımcıların personel bulma ve seçmede sosyal medyayı ne derece etkin bulduklarını saptamaya yöneliktir. $X$ ve $Y$ kuşağına uygulanan araştırma sonucunda, $Y$ kuşağı profesyonellerinin $X$ kuşağına göre personel bulmada sosyal ağ uygulamalarını orta seviyede daha fazla kullandıkları bulunmuştur. Personel seçme de ise kuşaklar arasında anlamlı farklılıklar bulunmamıştır.

Y kuşağına dair yurt içi ve yurt dışı alanyazın karşılaştırıldığında, yurt dışında yapılan araştırmalarda yer alan $Y$ kuşağı tanımlamalarının ülkemizi yansıtmadığı belirtilmektedir. Buradan hareketle, $Y$ kuşağ 1 için belirtilen özelliklerde ülkemiz sosyo-ekonomik ve kültürel şartlarından kaynaklanan farklılıkların olduğunu ve hatta bu farklılıkların okuldan okula bile gözlendiğini bildiren çalışma mevcuttur. Buna göre, Türkiye'nin kendi içerisinde bile tek tip bir Y kuşağı olmadığı, kültürel, ekonomik ve eğitim düzeyi gibi özelliklerine göre değişkenlik gösterebileceği bir Y kuşağı profili olduğu belirtilmektedir (Ekşili ve Antalyalı, 2017). Bu görüşü destekler biçimde, örneğin Bayramoğlu ve Şahin (2017) 1981 ve sonrasında doğan Türk Y kuşağının kariyer beklentileri açısından diğer ülkelerdeki Y kuşaklarına göre farklı beklentiler içinde olduğunu ortaya koymuştur.

Türkiye'de de diğer ülkelerde olduğu gibi sosyal medya kullanımının hızla arttığı ve hayatımızın hemen hemen her alanına girdiği dolayısıyla kuşaklar konusundaki çalışmaların yaygınlaştığı ve ölçme aracı geliştirmeye yönelik çabaların da bu gelişmelere paralel olarak devam ettiği görülmektedir. Buna rağmen halen kuşaklar arası benzerlik ve farklılıkları karşılaştırmak için çok boyutlu farklı veri toplama araçlarına ihtiyaç duyulmaktadır. Ülkemizdeki kuşakların diğer ülkelerdeki kuşaklara göre 
farklılıklar göstermesi durumundan hareketle de sosyal medya kuşaklarına yönelik ölçeklerin uyarlanma çalışmalarından daha çok kendi kültürel değerlerimiz, davranış kalıplarımız bağlamında geliştirilmesi önem taşımaktadır. Bu gerekçelerden hareketle araştırmada kuşakların çok boyutlu olarak incelenebilmesi, sosyal medya kullanımlarının ve pek çok alandaki değerlerinin (iş, aile, aykırılık) saptanabilmesi için ölçek geliştirilmesi amaçlanmıştır.

\section{Yöntem}

Bu çalışma farklı kuşakların sosyal medya kullanımlarının ve çeşitli boyutlardaki değerlerinin ortaya konabilmesi için ölçek geliştirmek amacına yönelik olarak tasarlanmış bir geçerlik ve güvenilirlik çalışmasıdır.

\section{Çalışma grubu}

Araştırmanın çalışma grubunu 516 kişi [Kadın n:294 (\%57); Erkek n: 222 (\%43)] oluşturmuştur. Çalışma grubunun kuşaklar bağlamında dağılımı Tablo 1'de verilmiştir.

Tablo 1. Araştırmanın çalışma grubunun kuşaklar bağlamında dă̆ılımı

\begin{tabular}{llll}
\hline Kuşaklar & Yıl aralı̆̆ & $\mathbf{n}$ & \% \\
\hline Sessiz Kuşak & $(1944$ öncesi) & - & - \\
Baby Boomers & $(1944-1964)$ & 30 & 5,8 \\
X Kuşağ1 & $(1965-1980)$ & 34 & 6,6 \\
Y Kuşağ1 & $(1981-1999)$ & 183 & 35,5 \\
Z Kuşağ & $(2000-2020)$ & 269 & 52,1 \\
\hline
\end{tabular}

Çalışma grubunun 395 kişisini $(\% 76,6)$ halen öğrenci olan gruplar oluşturmaktadır.

Çalışma grubunun öğrenci olan kısmının öğrenim gördükleri kademelere göre dağılımı Tablo 2'de verilmiştir. 
Tablo 2. Çalışma grubunda yer alan öğrencilerin öğrenim gördükleri kademelere göre dă̆ılımı

\begin{tabular}{lll}
\hline Öğrenim kademeleri & $\mathrm{n}$ & $\%$ \\
\hline Ortaokul & 214 & 54,2 \\
Lise & 57 & 14,4 \\
Yüksekokul & 12 & 3,0 \\
Lisans & 70 & 17,7 \\
Yüksek Lisans & 37 & 9,4 \\
Doktora & 5 & 1,3 \\
\hline Toplam & 395 & 100 \\
\hline
\end{tabular}

Çalışma grubunun şu an öğrenci olmayan 121 kişisinin ise $(\% 23,4)$ en son mezun olduğu öğrenim kademesi Tablo 3'de verilmiştir.

Tablo 3. Çalışma grubunda yer alan öğrenci olmayanların en son mezun olduğu öğrenim kademesine göre dă̆̆lımı

\begin{tabular}{lll}
\hline Öğrenim kademeleri & $\mathbf{n}$ & $\%$ \\
\hline İlkokul & 2 & 1,7 \\
Ortaokul & 5 & 4,1 \\
Lise & 20 & 16,5 \\
Yüksekokul & 10 & 8,3 \\
Lisans & 55 & 45,5 \\
Yüksek Lisans & 15 & 12,4 \\
Doktora & 14 & 11,6 \\
\hline Toplam & 121 & 100 \\
\hline
\end{tabular}

\section{Ölçeklerin Geliştirilmesi ve Verilerin Çözümlenmesi}

Ölçeğin geliştirilmesi sürecinde kuşaklara ait atfedilen özellikler (davranışlar, değerler vb.), ilgili kaynaklar taranarak ortaya çıkartılmış ve bu doğrultuda maddeler yazılmıştır. Ölçeğin madde havuzu ilk aşamada 63 maddeden oluşmuştur. Ölçek 5'li derecelemeli Likert türü bir ölçek olarak hazırlanmış ve her maddeye katılım, ilgili maddenin kişiye ne derecede uyduğunu belirlemek için “Bana Hiç Uygun Değil (1), Bana Az Uygun (2), Bana Orta Seviyede Uygun (3), Bana Çok Uygun (4), Bana Tamamen Uygun (5)" şeklinde ifadelendirilmiştir. Deneme ölçeğinden alınacak yüksek puanın daha yeni, Z kuşağına ait özellikleri gösterdiği; düşük puanın da 
"Baby Boomers" olarak adlandırılan eski kuşağa ait özellikleri gösterdiği varsayılmıştır.

Uzman görüşleri alınarak maddelerin ifadeleri, içerikleri gibi boyutlarda son düzenlemeler yapıldıktan sonra deneme ölçeği anlaşılırlığın s1nanması için ayrı yaşlardan pilot bir gruba (n:10) uygulanmış ve deneme ölçeğinin yapılan son ifade düzenlemeleriyle 63 maddeyle uygulanabileceğine karar verilmiştir. Uygulama sonucunda elde edilen verilerle yap1lan Açımlayıcı Faktör Analizi denemeleri (açıklanan varyans, boyutların adlandırılması, alt ölçeklerin birbirleriyle ve toplamla olan ilişkileri vb. açlardan) tatmin edici bulunmamıştır. Bu sonuçlardan hareketle maddeler temsil ettiği düşünülen boyutlara ayrıştırılarak her boyutun tek başına ele alınarak Açımlayıcı Faktör Analizi ile incelenmesine karar verilmiştir. $\mathrm{Bu}$ kapsamda üç boyut üzerinde çalışılmıştır.

Öncelikle her boyuta giren sorular madde toplam analizi ve iç tutarlılığa katkısı açısından incelenmiştir. Düşük ilişki değerlerinin bulunması veya maddenin çıkmasının iç tutarlılık değerini yükselttiği durumlarda maddeler elenmiştir. Bu değerlendirmenin ardından boyutların yapı geçerliğini belirlemek için Açımlayıcı Faktör Analizi Varimax Döndürme yapılarak uygulanmıştır. Verilerin faktör analizine uygunluğu Kaiser Meyer Olkin (KMO) katsayısı ve Bartlett Sphericity testi ile sınanmıştır. KMO değerinin 0,70 ve üzeri olması örneklem yeterliliğinin sağlanması açısından "iyi" (Sipahi, Yurtkoru ve Çinko, 2008); 0,80 ve üzeri olması ise "mükemmel" (Can, 2013) olarak değerlendirilmektedir. Benzer şekilde Bartlett Sphericity değerinin de $\mathrm{p}<0,05$ olması beklenmektedir. Faktör analizi sırasında faktör sayısına bir sınırlama getirilmemiştir. Eigen ve faktör yüklerinin kesme değerleri yapılan üç çalışmada farklı olarak ele alınmış ve bulgular kısmında açılanmıştır. Binişik maddelerin elenmesinde maddeler arasındaki farkın miktarının 0,10 olması kuralı dikkate alınmıştır.

Ölçeklerin yapı geçerliği kapsamında ayrıca ortaya çıkan faktörlerin birbirleriyle ve toplamla olan ilişkileri de gözden geçirilmiştir. Elde edilen korelasyon değerlerinin yorumlanmasında Büyüköztürk'ün (2002, s.32) belirttiği 0,30-0,70 arasındaki ilişki değerlerinin orta; 070 üzerindeki değerlerin de yüksek ilişkiye işaret ettiği kabulü dikkate alınmıştır.

Ölçeklerin ayırt edicilik geçerliği için her bir maddenin, ölçeğin toplamının ve alt ölçeklerin ayırt edicilik geçerliğine bakılmıştır. Her bir ölçek 
puanlandıktan sonra alınan puanlar sıralanmış ve \%27'lik alt çeyreğe giren kişilerle üst çeyreğe giren kişilerin puanları arasındaki farklılığı belirlenmesi için bağımsız grup t-testi uygulanmıştır.

Ölçeklerin güvenilirlik çalışmaları kapsamında ise madde analizi ve iç tutarlılık (Cronbach $\alpha$ ) katsayıları hesaplanmıştır. Sipahi, Yurtkoru ve Çinko (2008) Cronbach $\alpha$ değerinin 0,70 ve üzeri olduğu durumlarda ölçeğin güvenilir kabul edildiğini soru sayısının az olduğu durumlarda ise 0,60 ve üstü değerin yeterli olacağını belirmişlerdir. Bu çalışmada da ölçeklerin Cronbach $\alpha$ iç tutarlılık katsayıları yorumlanırken bu değerler ölçüt kabul edilmiştir.

\section{Bulgular}

\section{Sosyal Medya Kullanımı Ölçeği}

Çalışmanın bu kısmında Sosyal Medya Kullanımı genel başlığı altında ele alınan ölçeğe ait değerlendirmeler yapılmıştır. Ölçeğin deneme formunda yer alan 10 maddeye ait madde toplam ve madde çıartıldığında iç tutarlılık katsayısı hesaplamaları yapılmış ve başlangıçta 0,676 olan iç tutarlılık katsayısının iki maddenin çıkmasıyla yüksek değer aldığı görülmüştür. Ölçekten çıkartılan maddeler "Sosyal medyadaki ortamımı (arkadaşlık/oyun vb.) yüz yüze olana tercih ederim." ve "Sosyal medyada kimlerin çevrimiçi olduğunu sık sık kontrol ederim." maddeleridir. Faktör analizi öncesinde ölçekte kalan 8 maddenin madde toplam ilişki değerleri 0,463 ila 0,649 arasında değişmektedir.

Ölçeğin yapı geçerliliği kapsamında temel bileşenler analizi uygulanmıştır. Eigen değeri 0,8 ve faktör yükü kesme değeri de 0,30 olarak alınmıştır. Ölçeğin temel bileşenler analizine uygunluğu Kaiser Meyer Olkin (KMO) katsayısı ve Bartlett Sphericity testi ile değerlendirilmiştir. Elde edilen sonuçlara göre KMO değeri 0,856 ve Bartlett Sphericity ki kare değeri 1189,074 (sd:28; p<0,000) bulunmuştur. Bulunan KMO örnekleme yeterliliği değerinin değişkenler arasındaki ilişkilerin faktör analizine mükemmel derecede uygun olduğunu ortaya koymaktadır. Benzer şekilde Bartlett Sphericity değerinin de $p<0,05$ olması geliştirilmekte olan ölçeğe ait değişkenler arasında faktör analizi yapmaya yeterli düzeyde bir ilişki bulunduğu anlaşılmaktadır. 
Tablo 4'de faktör analizi sonucunda ortaya çıkan faktörler, madde faktör yükleri, faktör öz değerleri ve her bir faktörün varyans yüzdesi verilmiştir.

Ortaya çıkan alt ölçeklerde yer alan maddelerin içeriğine bakılarak bu alt ölçekler Süreklilik ve Yetkinlik olarak adlandırılmıştır.

Tablo 4. Sosyal Medya Kullanımı Ölçeği'ne ait faktör analizi sonuçları

\begin{tabular}{|c|c|c|c|c|}
\hline Faktörler & Madde & $\begin{array}{l}\text { Faktör } \\
\text { Yükü }\end{array}$ & $\begin{array}{l}\text { Faktör } \\
\text { Öz } \\
\text { Değeri }\end{array}$ & $\begin{array}{l}\text { Varyans } \\
\text { Yüzdesi }\end{array}$ \\
\hline \multirow{4}{*}{ Süreklilik } & $\begin{array}{l}\text { 1. Akıllı telefonumdan uzak kaldı- } \\
\text { ğımda kendimi eksik, huzursuz hisse- } \\
\text { derim. }\end{array}$ & 0,788 & \multirow{4}{*}{2,39} & \multirow{4}{*}{29,94} \\
\hline & $\begin{array}{l}\text { 2. Uyumadan önce ve uyandıktan he- } \\
\text { men sonra mutlaka sosyal medya he- } \\
\text { saplarımı kontrol ederim. }\end{array}$ & 0,729 & & \\
\hline & $\begin{array}{l}\text { 3. Mobil cihazlarımla (tablet, telefon } \\
\text { vs.) devamlı çevrimiçi/aktif bulunu- } \\
\text { rum. }\end{array}$ & 0,659 & & \\
\hline & $\begin{array}{l}\text { 4. Bir şey okuyup çalışırken sosyal } \\
\text { medya bağlantımı da kesmem. }\end{array}$ & 0,599 & & \\
\hline \multirow{4}{*}{ Yetkinlik } & $\begin{array}{l}\text { 5. Sosyal medya ve internet kullanarak } \\
\text { her işimi yapabilirim. }\end{array}$ & 0,806 & \multirow{5}{*}{2,16} & \multirow{4}{*}{27,02} \\
\hline & $\begin{array}{l}\text { 6. Günlük tüm etkinliklerimi (ko- } \\
\text { nuşma, oyun, banka alışveriş vb.) sos- } \\
\text { yal medya üzerinden yönetebilirim. }\end{array}$ & 0,751 & & \\
\hline & $\begin{array}{l}\text { 7. Yaşamımın her alanında sosyal } \\
\text { medyayı aktif kullanırım. }\end{array}$ & 0,664 & & \\
\hline & $\begin{array}{l}\text { 8. Aynı anda hem tablet, akıllı telefon } \\
\text { vb. kullanıp hem de diğer işlerimi ya- } \\
\text { pabilirim. }\end{array}$ & 0,512 & & \\
\hline Toplam & & & & 56,96 \\
\hline
\end{tabular}

Tablo 5. Sosyal Medya Kullanım Ölçeği ve Alt Ölçekleri Arasındaki İlişkiler

\begin{tabular}{cccc}
\hline Faktörler & Süreklilik & Yetkinlik & $\begin{array}{l}\text { Sosyal Medya } \\
\text { Kullanım Ölçeği } \\
\text { (Toplam Puan) }\end{array}$ \\
\hline Süreklilik & - & 0,631 & 0,912 \\
Yetkinlik & - & - & 0,894 \\
\hline
\end{tabular}


Faktör analizinden sonra ortaya çıkan Sosyal Medya Kullanımı Ölçeği'ne ait yapının (alt ölçeklerin) birbirleriyle ve toplam puanla olan ilişkilerine bakılmıştır. Elde edilen sonuçlar Tablo 5'de verilmiştir.

Tablo 5 incelendiğinde Sosyal Medya Kullanım Ölçeği'ni oluşturan alt ölçeklerin birbiriyle ilişkisinin beklendiği gibi orta $(\mathrm{r}: 0,631)$ ve toplamla ilişkisinin ise yüksek (r:0894 ve r:0,912) olduğu anlaşılmaktadır.

Sosyal Medya Kullanımı Ölçeği'nin ayırt edicilik geçerliliği kapsamında her bir maddenin, alt ölçek ve ölçeğin ayır ediciliğine bakılmıştır. Bu kapsamda puanlar yüksekten düşüğe doğru sıraya dizildikten sonra \%27'ye denk gelen 139'ar kişilik alt ve üst gruplar arasında bağımsız grup t-testi uygulanmıştır. Ölçeğin tüm maddelerinin $\mathrm{p}<0,01$ seviyesinde ayırt edici olduğu saptanmıştır. Alt ölçek ve ölçeğin toplamının da ayırt edici olduğu saptanmış ve sonuçlar Tablo 6' da verilmiştir.

Tablo 6. Sosyal Medya Kullanımı Ölçeği ve alt ölçeklerinin toplam puan ayırt ediciliklerine ilişkin bă̆ımsız grup t-testi analizi

\begin{tabular}{|c|c|c|c|c|c|c|c|c|}
\hline \multirow{2}{*}{ Faktörler } & \multirow{2}{*}{ Gruplar } & \multirow{2}{*}{$\mathbf{n}$} & \multirow{2}{*}{$\mathbf{x}$} & \multirow{2}{*}{ ss } & \multirow{2}{*}{$\mathrm{Sh}_{x}$} & \multicolumn{3}{|c|}{$t$ testi } \\
\hline & & & & & & $\mathbf{t}$ & sd & p \\
\hline \multirow{2}{*}{ Süreklilik } & Üst çeyrek & 139 & 16,35 & 1,92 & 0,16 & \multirow{2}{*}{50,30} & \multirow[b]{2}{*}{276} & \multirow{2}{*}{0,000} \\
\hline & Alt çeyrek & 139 & 6,25 & 1,37 & 0,11 & & & \\
\hline \multirow{2}{*}{ Yetkinlik } & Üst çeyrek & 139 & 16,44 & 1,85 & 0,15 & \multirow{2}{*}{47,03} & \multirow{2}{*}{276} & \multirow{2}{*}{0,000} \\
\hline & Alt çeyrek & 139 & 7,19 & 1,39 & 0,11 & & & \\
\hline \multirow{2}{*}{$\begin{array}{l}\text { Sosyal Medya } \\
\text { Kullanımı } \\
\text { (Toplam) }\end{array}$} & Üst çeyrek & 139 & 31,76 & 3,64 & 0,30 & \multirow[b]{2}{*}{46,09} & \multirow[b]{2}{*}{276} & \multirow[b]{2}{*}{0,000} \\
\hline & Alt çeyrek & 139 & 14,35 & 2,55 & 0,21 & & & \\
\hline
\end{tabular}

Tablo 6 genel olarak değerlendirildiğinde Sosyal Medya Ölçeği ve alt ölçeklerinin ayırt edicilik geçerliliğinin olduğu anlaşılmaktadır.

Güvenilirlik çalışmaları kapsamında Sosyal Medya Kullanımı Ölçeği'nin ve alt ölçeklerinin Cronbach $\alpha$ iç tutarlılık katsayıları hesaplanmış ve Tablo 7 'de verilmiştir.

Tablo 7. Sosyal Medya Kullanım Ölçeği ve alt ölçeklerinin iç tutarlılık katsayıları

\begin{tabular}{llc}
\hline Faktörler & Madde sayıs & Cronbach $\alpha$ \\
\hline Süreklilik & 4 & 0,721 \\
Yetkinlik & 4 & 0,734 \\
Sosyal Medya Kullanımı (Toplam) & 8 & 0,824 \\
\hline
\end{tabular}


Tablo 7'deki iç tutarlılık katsayıları incelendiğinde Sosyal Medya Kullanımı Ölçeği'nin toplamının ve alt ölçeklerinin iç tutarlılık güvenilirliklerinin iyi olduğu söylenebilir.

\section{Çalışma Hayatı Ölçeği}

Çalışmanın bu kısmında Çalışma Hayatı genel başlığı altında ele alınan ölçeğe ait değerlendirmeler yapılmıştır. Ölçeğin deneme formunda yer alan 13 maddeye ait madde toplam ve madde çıkartıldığında iç tutarlılık katsayısı hesaplamaları yapılmış ve başlangıçta 0,558 olan iç tutarlılık katsayısının dört maddenin çıkmasıyla yüksek değer aldığı görülmüştür. Ayrıca bir madde de madde toplam ilişkisinin düşük (r:0,15) olması sebebiyle ölçekten çıkartılmıştır. Ölçekten çıkartılan maddelerden bazıları "Çalışmayı yaşamak için isterim hayatımda daha önemli şeyler var.", "Çalıştığım yerde eğer kısa sürede terfi alamazsam işimi değiştirebilirim.", "Yıllarca çalışma garantisi olmasa da maddiyatı yüksek işi tercih ederim." şeklinde ifade edilen maddelerdir. Faktör analizi öncesinde ölçekte kalan 8 maddenin madde toplam ilişki değerleri 0,474 ila 0,214 arasında değiş̧mektedir.

Ölçeğin yapı geçerliliği kapsamında temel bileşenler analizi uygulanmıştır. Eigen değeri 1 ve faktör yük kesme değeri de 0,30 olarak alınmıştır. Ölçeğin temel bileşenler analizine uygunluğu Kaiser Meyer Olkin (KMO) katsayısı ve Bartlett Sphericity testi ile değerlendirilmiştir. Elde edilen sonuçlara göre KMO değeri 0,784 ve Bartlett Sphericity ki kare değeri 548,012 (sd:28; p<0,000) bulunmuştur. Bulunan KMO örnekleme yeterliliği değerinin değişkenler arasındaki ilişkilerin faktör analizine iyi derecede uygun olduğunu ortaya koymaktadır. Benzer şekilde Bartlett Sphericity değerinin de $p<0,05$ olması geliştirilmekte olan ölçeğe ait değiş̧kenler arasında faktör analizi yapmaya yeterli düzeyde bir ilişki bulunduğu anlaşılmaktadir.

Tablo 8'de faktör analizi sonucunda ortaya çıkan faktörler, madde faktör yükleri, faktör öz değerleri ve her bir faktörün varyans yüzdesi verilmiştir. Ortaya çıan alt ölçeklerde yer alan maddelerin içeriğine bakılarak bu alt ölçekler İşe Önem Verme ve Kurallara Uyma olarak adlandırılmıştir. 
Tablo 8. Çalışma Hayatı Ölçeği'ne faktör analizi sonuçları

\begin{tabular}{|c|c|c|c|c|}
\hline Faktörler & Madde & $\begin{array}{l}\text { Faktör } \\
\text { Yükü }\end{array}$ & $\begin{array}{l}\text { Faktör Öz } \\
\text { Değeri }\end{array}$ & $\begin{array}{l}\text { Varyans } \\
\text { Yüzdesi }\end{array}$ \\
\hline \multirow{5}{*}{$\begin{array}{l}\text { İşe Önem } \\
\text { Verme }\end{array}$} & $\begin{array}{l}\text { 1. Kariyerimde ilerlemek için aynı ku- } \\
\text { rumda kalıp belirli bir süre emek vermem } \\
\text { gerektiğine inanırım. }\end{array}$ & 0,744 & \multirow{5}{*}{2,24} & \multirow{5}{*}{28,03} \\
\hline & $\begin{array}{l}\text { 2. İş hayatında kademe atlamak için sabre- } \\
\text { dip çalışmak gerektiğine inanırım. }\end{array}$ & 0,702 & & \\
\hline & $\begin{array}{l}\text { 3. Çalışma hayatı yaşamın en önemli parça- } \\
\text { sıdır. }\end{array}$ & 0,674 & & \\
\hline & $\begin{array}{l}\text { 4. Aynı işte senelerce çalışmak bana güven } \\
\text { verir. }\end{array}$ & 0,476 & & \\
\hline & $\begin{array}{l}\text { 5. Maddi karşılığı yeterli olmasa da içinde } \\
\text { bulunduğum kurumun/grubun başarısı } \\
\text { için fazlasıyla çalışırım. }\end{array}$ & 0,460 & & \\
\hline \multirow{3}{*}{$\begin{array}{l}\text { Kurallara } \\
\text { Uyma }\end{array}$} & $\begin{array}{l}\text { 6. Kuralları ve çalışma saatleri belirgin olan } \\
\text { işlerin bana göre olmadığını düşünürüm. }\end{array}$ & 0,855 & \multirow{3}{*}{1,44} & \multirow{3}{*}{18,06} \\
\hline & $\begin{array}{l}\text { 7. Çalışma saatlerinin belirgin ve düzenli } \\
\text { olduğu bir işi tercih ederim. }\end{array}$ & 0,608 & & \\
\hline & $\begin{array}{l}\text { 8. Disiplinin ön plana alındığ } \text { bir yerde ça- } \text { lışmak isterim. }\end{array}$ & 0,478 & & \\
\hline Toplam & & & & 46,09 \\
\hline
\end{tabular}

Faktör analizinden sonra ortaya çıkan Çalışma Hayatı Ölçeği'ne ait yapının (alt ölçeklerin) birbirleriyle ve toplam puanla olan ilişkilerine bakılmıştır. Elde edilen sonuçlar Tablo 9'da verilmiştir.

Tablo 9. Çalışma Hayatı Ölçeği ve Alt Ölçekleri Arasındaki İlişkiler

\begin{tabular}{llll}
\hline \multirow{2}{*}{ Faktörler } & $\begin{array}{l}\text { İşe } \\
\text { Önem Verme }\end{array}$ & $\begin{array}{l}\text { Kurallara } \\
\text { Uyma }\end{array}$ & $\begin{array}{l}\text { Çalışma Hayatı Ölçeği } \\
\text { (Toplam Puan) }\end{array}$ \\
\hline İşe Önem Verme & - & 0,389 & 0,892 \\
Kurallara Uyma & - & - & 0,763 \\
\hline
\end{tabular}

Tablo 9 incelendiğinde Çalışma Hayatı Ölçeği'ni oluşturan alt ölçeklerin birbirleriyle ilişkisinin beklendiği gibi orta (r:0,389) ve toplamla ilişkisinin ise yüksek (r:0,893 ve r:0,763) olduğu anlaşılmaktadır.

Çalışma Hayatı Ölçeği'nin ayırt edicilik geçerliliği kapsamında her bir maddenin, alt ölçek ve ölçeğin ayır ediciliğine bakılmıştır. Bu kapsamda puanlar yüksekten düşüğe doğru sıraya dizildikten sonra \%27'ye denk gelen 139'ar kişilik alt ve üst gruplar arasında bağımsız grup t-testi uygulanmıştır. Ölçeğin tüm maddelerinin $p<0,01$ seviyesinde ayırt edici olduğu 
saptanmıştır. Alt ölçek ve ölçeğin toplamının da ayırt edici olduğu saptanmış ve sonuçlar Tablo 10'da verilmiştir.

Tablo 10. Çalışma Hayatı Ölçeği ve alt ölçeklerinin toplam puan ayırt ediciliklerine ilişkin bağımsız grup t-testi analizi

\begin{tabular}{|c|c|c|c|c|c|c|c|c|}
\hline \multirow{2}{*}{ Faktörler } & \multirow{2}{*}{ Gruplar } & \multirow{2}{*}{$\mathbf{n}$} & \multirow{2}{*}{$x$} & \multirow{2}{*}{ ss } & \multirow{2}{*}{$\operatorname{Sh}_{x}$} & \multicolumn{3}{|c|}{$\mathrm{t}$ testi } \\
\hline & & & & & & $t$ & sd & p \\
\hline \multirow{2}{*}{$\begin{array}{l}\text { İşe Önem } \\
\text { Verme }\end{array}$} & Üst çeyrek & 139 & 16,23 & 2,18 & 0,18 & \multirow{2}{*}{40,90} & \multirow{2}{*}{276} & \multirow{2}{*}{0,000} \\
\hline & Alt çeyrek & 139 & 7,06 & 1,48 & 0,12 & & & \\
\hline \multirow{2}{*}{$\begin{array}{l}\text { Kurallara } \\
\text { Uyma }\end{array}$} & Üst çeyrek & 139 & 10,25 & 1,40 & 0,11 & \multirow{2}{*}{46,69} & \multirow{2}{*}{276} & \multirow{2}{*}{0,000} \\
\hline & Alt çeyrek & 139 & 3,79 & 0,82 & 0,06 & & & \\
\hline \multirow{2}{*}{$\begin{array}{l}\text { Çalışma } \\
\text { Hayatı } \\
\text { (Toplam) }\end{array}$} & Üst çeyrek & 139 & 25,17 & 3,03 & 0,25 & \multirow[b]{2}{*}{43,34} & \multirow[b]{2}{*}{276} & \multirow[b]{2}{*}{0,000} \\
\hline & Alt çeyrek & 139 & 12,02 & 1,88 & 0,16 & & & \\
\hline
\end{tabular}

Tablo 10 genel olarak değerlendirildiğinde Sosyal Medya Ölçeği ve alt ölçeklerinin ayırt edicilik geçerliliğinin olduğu anlaşılmaktadır.

Güvenilirlik çalışmaları kapsamında Çalışma Hayatı Ölçeği'nin ve alt ölçeklerinin Cronbach $\alpha$ iç tutarlılık katsayıları hesaplanmış ve Tablo 11 'de verilmiştir.

Tablo 11. Çalışma Hayatı Ölçeği ve alt ölçeklerinin iç tutarlılık katsayıları

\begin{tabular}{lll}
\hline Faktörler & Madde sayısı & Cronbach $\boldsymbol{\alpha}$ \\
\hline İşe Önem Verme & 5 & 0,64 \\
Kurallara Uyma & 3 & 0,47 \\
Çalışma Hayatı (Toplam) & 8 & 0,68 \\
\hline
\end{tabular}

Tablo 11'deki iç tutarlılık katsayıları incelendiğinde Çalışma Hayatı Ölçeği'nin toplamının ve İşe Önem Verme alt ölçeğinin iç tutarlılık güvenilirliğinin yeterli olduğu söylenebilir. Kurallara Uyma alt ölçeği ise beklenenden daha düşük iç tutarlılık değerine sahiptir.

\section{Farklılıkları Kabul}

Çalışmanın bu kısmında Farklılıkları Kabul genel başlığı altında ele alınan ölçeğe ait değerlendirmeler yapılmıştır. Ölçeğin deneme formunda yer alan 11 maddeye ait madde toplam ve madde çıkartıldığında iç tutarlılık 
katsayısı hesaplamaları yapılmış ve başlangıçta 0,722 olan iç tutarlılık katsayısının iki maddenin çıkmasıyla yüksek değer aldığı görülmüştür. Ölçekten çıkartılan maddeler "Kendi görüşüme ters olan bir olay karşısında doğrusunu anlatana kadar direnirim." ve "Çevremde farklı kültürel değerler sahip kişilerin olması beni rahatsız eder." maddeleridir. Faktör analizi öncesinde ölçekte kalan 9 maddenin madde toplam ilişki değerleri 0,354 ila 0,496 arasında değişmektedir.

Tablo 12. Farklılıkları Kabul Ölçeği'ne ait faktör analizi sonuçları

\begin{tabular}{|c|c|c|c|c|}
\hline Faktörler & Madde & $\begin{array}{l}\text { Faktör } \\
\text { Yükü }\end{array}$ & $\begin{array}{l}\text { Faktör } \\
\text { Öz } \\
\text { Değeri }\end{array}$ & $\begin{array}{l}\text { Varyans } \\
\text { Yüzdesi }\end{array}$ \\
\hline \multirow{3}{*}{$\begin{array}{l}\text { Farklı } \\
\text { Dini/Etnik } \\
\text { Yapıları } \\
\text { Kabul }\end{array}$} & $\begin{array}{l}\text { 1. Farklı dini inançtan arkadaşlarımın ol- } \\
\text { ması beni rahatsız eder. }\end{array}$ & 0,822 & \multirow{3}{*}{1,85} & \multirow{3}{*}{20,60} \\
\hline & $\begin{array}{l}\text { 2. Farklı dini inançtan olan insanların yer } \\
\text { aldığı ortak çalışma gruplarına katılabili- } \\
\text { rim. }\end{array}$ & 0,790 & & \\
\hline & $\begin{array}{l}\text { 3. Farklı etnik gruplara ait kişilerle dost- } \\
\text { luk kurmam. }\end{array}$ & 0,478 & & \\
\hline \multirow{3}{*}{$\begin{array}{l}\text { Farklı Dış } \\
\text { Görünüşleri } \\
\text { Kabul }\end{array}$} & $\begin{array}{l}\text { 4. Burnuna, kaşına, diline takı (piercing) } \\
\text { takan birini kültürel olarak kaybolmuş } \\
\text { kabul ederim. }\end{array}$ & 0,804 & \multirow{3}{*}{1,71} & \multirow{3}{*}{19,07} \\
\hline & $\begin{array}{l}\text { 5. Vücudunun çeşitli yerlerine hızma/pi- } \\
\text { ercing takmış birine acırım. }\end{array}$ & 0,687 & & \\
\hline & $\begin{array}{l}\text { 6. İşveren olsam vücudunun her tara- } \\
\text { fında dövmeler olan birini tercih etmem. }\end{array}$ & 0,683 & & \\
\hline \multirow{3}{*}{$\begin{array}{l}\text { Farklı Düşün- } \\
\text { celeri/Değer- } \\
\text { leri Kabul }\end{array}$} & $\begin{array}{l}\text { 7. Sosyal medyada aykırı görüşe sahip } \\
\text { olanlarla bağlantımı keserim. }\end{array}$ & 0,764 & \multirow{3}{*}{1,71} & \multirow{3}{*}{19,05} \\
\hline & $\begin{array}{l}\text { 8. Aykırı değer tercihleri olan kişileri aile } \\
\text { çevremde görmek istemem. }\end{array}$ & 0,716 & & \\
\hline & $\begin{array}{l}\text { 9. Aykırı yaşam tarzı olan biriyle arka- } \\
\text { daşlık etmek beni rahatsız eder. }\end{array}$ & 0,540 & & \\
\hline \multicolumn{2}{|l|}{ Toplam } & & & 58,73 \\
\hline
\end{tabular}

Ölçeğin yapı geçerliliği kapsamında temel bileşenler analizi uygulanmıştır. Eigen değeri 0,9 ve faktör yükü kesme değeri de 0,30 olarak alınmıştır. Ölçeğin temel bileşenler analizine uygunluğu Kaiser Meyer Olkin (KMO) katsayısı ve Bartlett Sphericity testi ile değerlendirilmiştir. Elde edilen sonuçlara göre KMO değeri 0,803 ve Bartlett Sphericity ki kare değeri 911,386 (sd:36; p<0,000) bulunmuştur. Bulunan KMO örnekleme ye- 
terliliği değerinin değişkenler arasındaki ilişkilerin faktör analizine mükemmel derecede uygun olduğunu ortaya koymaktadır. Benzer şekilde Bartlett Sphericity değerinin de $\mathrm{p}<0,05$ olması geliştirilmekte olan ölçeğe ait değişkenler arasında faktör analizi yapmaya yeterli düzeyde bir ilişki bulunduğu anlaşılmaktadır.

Tablo 12'de faktör analizi sonucunda ortaya çıkan faktörler, madde faktör yükleri, faktör öz değerleri ve her bir faktörün varyans yüzdesi verilmiştir. Ortaya çıkan alt ölçeklerde yer alan maddelerin içeriğine bakılarak bu alt ölçekler Farklı Dini/Etnik Yapıları Kabul, Farklı Dış Görünüşleri Kabul ve Farklı Düşünceleri/Değerleri Kabul olarak adlandırılmıştır.

Faktör analizinden sonra ortaya çıkan Farklılıkları Kabul Ölçeği'ne ait yapının (alt ölçeklerin) birbirleriyle ve toplam puanla olan ilişkilerine bakılmıştır. Elde edilen sonuçlar Tablo 13'de verilmiştir.

Tablo 13. Farklılıkları Kabul Ölçeği ve alt ölçeklerinin iç tutarlılık katsayıları

\begin{tabular}{llllll} 
& $\begin{array}{l}\text { Farklı } \\
\text { Etnik } \\
\text { ları } \\
\text { Kabul }\end{array}$ & $\begin{array}{l}\text { Dini/ } \\
\text { Yapı- }\end{array}$ & $\begin{array}{l}\text { Farklı Dişrler } \\
\text { Görünüş- } \\
\text { leri } \\
\text { Kabul }\end{array}$ & $\begin{array}{l}\text { Farklı } \\
\text { Değerleri Kabul }\end{array}$ & $\begin{array}{l}\text { Düsünceleri/ } \\
\text { Fabklılı̈ları Ölçeği } \\
\text { Koplam } \\
\text { Puan) }\end{array}$ \\
\hline $\begin{array}{l}\text { Farklı Dini/Etnik } \\
\text { Yapıları Kabul }\end{array}$ & - & 0,41 & 0,46 & 0,79 \\
$\begin{array}{l}\text { Farklı Dış } \\
\text { Görünüşleri Kabul }\end{array}$ & - & - & 0,40 & 0,78 \\
$\begin{array}{l}\text { Farklı Düşünce- } \\
\text { leri/ Değerleri Ka- } \\
\text { bul }\end{array}$ & & & & 0,79 \\
\hline
\end{tabular}

Tablo 13 incelendiğinde Farklılıkları Kabul Ölçeği'ni oluşturan alt ölçeklerin birbirleriyle ilişkisinin beklendiği gibi orta (r:0,41; r:0,46 ve r:0,40) ve toplamla ilişkisinin ise yüksek (r:0,78 ve r:0,79) olduğu anlaşllmaktadır.

Farklılıkları Kabul Ölçeği'nin ayırt edicilik geçerliliği kapsamında her bir maddenin, alt ölçek ve ölçeğin ayırt ediciliğine bakılmıştır. Bu kapsamda puanlar yüksekten düşüğe doğru siraya dizildikten sonra \%27'ye denk gelen 139'ar kişilik alt ve üst gruplar arasında bağımsız grup t-testi uygulanmıştır. Ölçeğin tüm maddelerinin $p<0,01$ seviyesinde ayırt edici olduğu saptanmıştır. Alt ölçek ve ölçeğin toplamının da ayırt edici olduğu saptanmış ve sonuçlar Tablo 14'de verilmiştir. 
Tablo 14. Farklılıkları Kabul Ölçeği ve alt ölçeklerinin toplam puan ayırt ediciliklerine ilişkin bă̆ımsız grup t-testi analizi

\begin{tabular}{|c|c|c|c|c|c|c|c|c|}
\hline \multirow{2}{*}{ Faktörler } & \multirow{2}{*}{ Gruplar } & \multirow{2}{*}{$\mathbf{n}$} & \multirow{2}{*}{$x$} & \multirow{2}{*}{ ss } & \multirow{2}{*}{$\operatorname{Sh}_{x}$} & \multicolumn{3}{|c|}{$\mathrm{t}$ testi } \\
\hline & & & & & & $t$ & sd & $p$ \\
\hline \multirow{2}{*}{$\begin{array}{l}\text { Farklı Dini/Etnik } \\
\text { Yapıları Kabul }\end{array}$} & Üst çeyrek & 139 & 14,90 & 0,29 & 0,02 & \multirow{2}{*}{52,41} & \multirow{2}{*}{276} & \multirow{2}{*}{0,000} \\
\hline & Alt çeyrek & 139 & 7,46 & 1,64 & 0,13 & & & \\
\hline \multirow{2}{*}{$\begin{array}{l}\text { Farklı Dış } \\
\text { Görünüşleri Kabul }\end{array}$} & Üst çeyrek & 139 & 14,79 & 0,40 & 0,03 & \multirow{2}{*}{52,49} & \multirow{2}{*}{276} & \multirow{2}{*}{0,000} \\
\hline & Alt çeyrek & 139 & 6,62 & 1,79 & 0,15 & & & \\
\hline \multirow{2}{*}{$\begin{array}{l}\text { Farklı Düşünceleri/ } \\
\text { Değerleri Kabul }\end{array}$} & Üst çeyrek & 139 & 13,71 & 1,12 & 0,09 & \multirow{2}{*}{46,17} & \multirow{2}{*}{276} & \multirow{2}{*}{0,000} \\
\hline & Alt çeyrek & 139 & 6,00 & 1,61 & 0,13 & & & \\
\hline \multirow{2}{*}{$\begin{array}{l}\text { Farklılıkları Kabul } \\
\text { Ölçeği } \\
\text { (Toplam Puan) }\end{array}$} & Üst çeyrek & 139 & 41,82 & 2,17 & 0,18 & \multirow[b]{2}{*}{57,88} & \multirow[b]{2}{*}{276} & \multirow[b]{2}{*}{0,000} \\
\hline & Alt çeyrek & 139 & 23,20 & 3,10 & 0,26 & & & \\
\hline
\end{tabular}

Tablo 14 genel olarak değerlendirildiğinde Farklılıkları Kabul Ölçeği ve alt ölçeklerinin ayırt edicilik geçerliliğinin olduğu anlaşılmaktadır.

Güvenilirlik çalışmaları kapsamında Farklılıkları Kabul Ölçeği'nin ve alt ölçeklerinin Cronbach $\alpha$ iç tutarlılık katsayıları hesaplanmış ve Tablo $15^{\prime}$ de verilmiştir.

Tablo 15. Farklılıkları Kabul Ölçeği ve alt ölçeklerinin iç tutarlılık katsayıları

\begin{tabular}{|c|c|c|}
\hline Faktörler & Madde sayısı & Cronbach $\alpha$ \\
\hline Farklı Dini/Etnik Yapıları Kabul & 3 & 0,67 \\
\hline Farklı Dış Görünüşleri Kabul & 3 & 0,63 \\
\hline Farklı Düşünceleri/Değerleri Kabul & 3 & 0,56 \\
\hline $\begin{array}{l}\text { Farklılıkları Kabul Ölçeği } \\
\text { (Toplam Puan) }\end{array}$ & 9 & 0,77 \\
\hline
\end{tabular}

Tablo 15'deki iç tutarlılık katsayıları incelendiğinde Farklılıkları Kabul Ölçeği'nin toplamının, Farklı Dini/Etnik Yapıları Kabul ve Farklı Dış Görünüşleri Kabul alt ölçeklerinin iç tutarlılık güvenilirliğinin yeterli olduğu söylenebilir. Farklı Düşünceleri/Değerleri Kabul alt ölçeği ise beklenenden daha düşük iç tutarlılık değerine sahiptir.

\section{Sonuç}

$\mathrm{Bu}$ araştırmada farklı kuşakların sosyal medya kullanımı, çalışma hayatı ve farklılıkların kabulü boyutları açısından davranış ve değerlerini ortaya 
koymak amacıyla bir dizi ölçek geliştirme çalışması gerçekleştirilmiştir. Yapılan çalışma sonucunda üç farklı ve birbirinden bağımsız ölçek ortaya çıkmıştır. Ölçeklerin ortak noktası maddelerin farklı kuşaklara atfedilen özellikleri (davranışları/değerleri) içeriyor olmasıdır.

Her üç ölçek de 5'li derecelemeli Likert türü ölçek olarak hazırlanmış ve her maddeye katılım, ilgili maddenin kişiye ne derecede uyduğunu belirlemek için “Bana Hiç Uygun Değil (1), Bana Az Uygun (2), Bana Orta Seviyede Uygun (3), Bana Çok Uygun (4), Bana Tamamen Uygun (5)" şeklinde ifadelendirilmiştir. Ölçeklerden alınacak yüksek puanın daha yeni, Z kuşağına ait özellikleri gösterdiği; düşük puanın da "Baby Boomers" olarak adlandırılan eski kuşağa ait özellikleri gösterdiği varsayılmıştır. Ölçekten alınacak puanların (veya puan aralıklarının) tek başına kuşaklara aidiyet konusunda bir sınıflama yapılmasını sağlaması mümkün görülmediğinden alınacak puanların yüksek puandan düşük puana doğru yeni Z kuşağı değer ve davranışları ile eski “Baby Boomers" kuşağı değer ve davranışları arasında bir dağılımı ${ }^{8}$ ortaya koyması beklenmektedir.

Bu bağlamda ortaya konulan ilk ölçek Sosyal Medya Kullanım Ölçeği'dir. Sosyal Medya Kullanım Ölçeği, Süreklilik ve Yetkinlik alt ölçeklerinden oluşmaktadır. Süreklilik alt ölçeği, kişinin sosyal medya etkinlikleri ile yoğun olarak meşgul olmasını, sosyal medyada sürekli olarak bulunmasını; Yetkinlik alt ölçeği ise sosyal medya ortamında gerçekleştirilebilecek çeşitli günlük yaşam etkinliklerini yapabilmede yeterli olmasını içermektedir. Sosyal Medya Kullanım Ölçeği'nde ters dönmüş madde bulunmamakta ve yüksek puan kişinin sosyal medya ile daha fazla meşgul olduğunu ve kullanım açısından yetkin olduğunu ortaya koymaktadır.

Araştırma kapsamında ortaya konan ikinci ölçek ise Çalışma Hayatı Ölçeği'dir. Çalışma Hayatı Ölçeği, İşe Önem Verme ve Kurallara Uyma alt ölçeklerinden oluşmaktadır. İşe Önem Verme alt ölçeği, kişinin iş hayatına ve çalışmaya verdiği önemi, çalıştı̆̆ iş yerinde sürekli olma çabasını ve çalıştığı işyerine adanmışlığını; Kurallara Uyma alt ölçeği ise çalışma ortamının disiplinli ve kurallı olmasına ilişkin yönelimini/tercihini içerir. Çalışma Hayatı Ölçeği'nin İşe Önem Verme alt ölçeğinde yer alan tüm

\footnotetext{
8 "Bir toplumda, bir kümede incelenen bir veya birçok özelliğin zamana, yere, seçilen herhangi bir değişkene göre hesaplanan sayısal ve oransal dağılışı” (TDK Güncel Sözlük 17.03.2019 tarihinde tdk.gov.tr adresinden erişilmiştir.)
} 
maddeler (1 ila 5) tersten puanlanmalıdır. Dolayısıyla bu maddelerden alınan yüksek puan işte yükselmede sabırsızlığı, çalışmanın hayatın önemli bir parçası olmadığını ve çalışılan işe bağlılı̆̆ın/sadakatin az olduğunu ortaya koymaktadır. Aynı ölçekte yer alan Kurallara Uyma alt ölçeğinde ise 7 ve 8 . maddeler tersten puanlanmalıdır. Bu alt ölçekte de alınan yüksek puan disiplinin ve belirgin kuralların hâkim olduğu bir işin tercih edilmediğini ortaya koymaktadır.

Araştırma kapsamında ortaya konan üçüncü ölçek ise Farklılıkları Kabul Ölçeği'dir. Farklılıkları Kabul Ölçeği, Farklı Dini/Etnik Yapıları Kabul, Farklı Dış Görünüşleri Kabul ve Farklı Düşünceleri/Değerleri Kabul alt ölçeklerinden oluşmaktadır. Farklılıkları Kabul Ölçeği, kişinin farklı dini/etnik aidiyet sahibi, farklı dış görünüş ve düşüncelerde ve yaşam değerlerine sahip kişileri iş, aile ortamı gibi ortamlarda kabulünü ve bu gruplara ilişkin önyargılarını içerir. Farklılıkları Kabul Ölçeği'nin Farklı Dini/Etnik Yapıları Kabul alt ölçeğinde yer alan 1 ve 3. maddeler; Farklı Dış Görünüşleri Kabul ve Farklı Düşünceleri/Değerleri Kabul alt ölçeğindeki tüm maddeler tersten puanlanmalıdır. Bu alt ölçeklerden alınan yüksek puan farklılıkların daha yüksek oranda kabul edildiğini ortaya koymaktadır.

Geliştirilen ölçeklerin kuşakların farklı davranış ve değerleri kapsamında yapılacak çalışmalarda ayrı ayrı veya bir batarya olarak birlikte kullanılmasının mümkün olduğu düşünülmektedir. Geliştirilen ölçeklerin sosyal medyanın her geçen gün yoğun olarak kullanıldığı çağımızda, sosyal medya kullanımı, iş yaşamı ve farklılıkların kabulü gibi göze çarpan ve önemli konularda kuşaklar arasında yapılacak karşılaştırma çalışmalarında yararlanılabileceği bu sayede yönelimlerin izlenebileceği umulmaktadir. 


\title{
EXTENDED ABSTRACT
}

\section{Development of a Set of Scales toward the Use of Social Media and Values of Generations in Social Media Age}

\author{
Levent Deniz - Aylin Tutgun-Ünal
}

Marmara University

The concept of generation can be defined as all the people of about the same age within a society. The generations are named under some classifications not only based on the age groups depending their birth dates but also the political and technological developments of the generations (age groups) they live in. Although there are various naming and slightly different year ranges, Silent Generation (1927-1945), Baby Boomer (19461964), Gen X (1965-1974), Gen Y (1980-1999), Gen Z (2000-...) are widely accepted to define the generations (Berkup, 2014; Dewanti ve Indrajit, 2018; Toruntay, 2011; Tutgun-Ünal, 2013). The researchers all over the world, especially social scientists, try to understand the values and behaviors of different generations towards their relations with their families/friends, consuming behaviors, working values/habits and so on. Gen $\mathrm{Y}$ is the generation where the intergenerational differences are felt most prominently. According to the population statistics in Turkey Gen Y and Gen $Z$ constitute the $45 \%$ of the whole population (TÜIK, 2018). This high proportion of Gen $Y$ and Z canalized many researchers to do studies with these generations but still most of the studies are conducted with Gen $X$ and $\mathrm{Y}$ as focus of interest and ease of reaching target population and collecting data. While collecting data about the values and behaviors of generations, the researcher use different techniques such as interviews, observations, questionnaires and standardized scales (Akdemir et al., 2013; Börü and Yurtkoru, 2016; Ekşili and Antalyalı, 2017; Erdal, 2018). As the social/technological changes occur increasingly in the society the reflections of these changes are monitored by newly developed scales based on 
the improvements. In another word to understand, to monitor the values and behaviors of generations it is still needed new scales to be developed.

The main aim of this research is to develop a scale to measure the values and behaviors of different generations. The study group of the research consisted of 516 people [Female n: 294 (57\%); Male n:222 (43\%)] from different generations [Baby Boomer n:30 (5,8\%); Gen X n:34 (6,6\%); Gen Y n:183 (35,5\%); Gen Z n: 269 (52,1\%)]. The study group also consisted of students (n:395, 76,6\%) from different levels, schools/universities and non students (n:121, 23,4\%) from various education levels and professions.

An item pool of 63 items was formed at the first phase of the scale development basing on the values and behaviors to be referred to generations in the literature. The scale is a five point Likert type scale and the acceptance of each item was worded from "Not totally convenient/suitable to me" to "Totally convenient/suitable to me". It is assumed that higher scores obtained from the scale reflect the characteristics of Gen $\mathrm{Z}$ and lower scores of Baby Boomers. The first construct validity and reliability analysis were not found satisfactory to form an overall structure. Basing on these results researchers decided to categorize all 63 items according to the dimensions they assumed to represent and then to repeat factor analysis to evaluate the construct validity. At the first hand three dimensions were studied. Corrected item analysis and internal reliability analysis using Cronbach's Alpha was computed to decide each items' contribution to the scale and the exploratory factor analysis was executed then. The last phase of the validity analysis was item discrimination analysis. The internal consistency reliability of the scales was also performed by Cronbach's Alpha value. All validity and reliability analysis revealed three independent scales.

The first scale was named as Social Media Usage Scale. Social Media Usage Scale has two sub scales named as "Continuity" (4 items) and "Competence" (4 items). Cumulative percentage of variance of Social Media Usage Scale is $56,96 \%$ while the other sub scales $29,94 \%$ and $27,02 \%$ respectively. Cronbach's Alpha Internal consistency value of Social Media Usage Scale was found as 0,82; while the other sub scales 0,72 and 0,73 respectively. One item for each sub scale is given as an example: "I don't cut off my social media connection while reading/studying something." 
(Continuity); "I can use social media actively in every area of my life" (Competence).

The second scale was named as Work Life Scale. Work Life Scale has also two sub scales named as "Giving Importance to Work" (5 items) and "Obeying the Rules" (3 items). Cumulative percentage of variance of Work Life Scale is $46,09 \%$ while the other sub scales $28,03 \%$ and $18,06 \%$ respectively. Cronbach's Alpha Internal consistency value of Work Life Scale was found as 0,68 while the other sub scales 0,64 and 0,47 respectively. One item for each sub scale is given as an example: "Work life is the most important part of my life." (Giving Importance to Work); "I prefer a job where working hours are standard and predictable." (Obeying the Rules).

The third scale was named as Acceptance of Diversity Scale. Acceptance of Diversity Scale has three sup scales named as "Acceptance of Diverse Religions/Ethnicities" (3 items), "Acceptance of Diverse Appearances" (3 items) and "Acceptance of Diverse Ideas/Values" (3 items). Cumulative percentage of variance of Acceptance of Diversity Scale 58,73\% while the other sub scales 20,60\%, 19,07 and 19,05 respectively. Cronbach's Alpha Internal consistency value of Acceptance of Diversity Scale was found as 0,77 while the other sub scales $0,67,0,63$ and 0,56 respectively. One item for each sub scale is given as an example: "I don't make friend with people who belong to different ethnic groups." (Acceptance of Diverse Religions/Ethnicities); "I pity to someone who has body piercing." (Acceptance of Diverse Appearances); "I cut off my connection those who have heresy in social media." (Acceptance of Diverse Ideas/Values).

It is expected that the scales will be used as independently or as a battery in whole by the researcher for the further studies to understand and monitor the values and behaviors of generation in the social media age.

\section{Kaynakça / References}

Akdemir, A., Konakay, G., Demirkaya, H., Noyan, A., Demir, B., Ağ, C. vd. (2013). Y kuşağının kariyer algısı, kariyer değişimi ve liderlik tarzı beklentilerinin araştırılması. Ekonomi ve Yönetim Araştırmaları Dergisi, 2(2), 11-42. 
Alwin, D.F. ve Mccammon, R.J. (2007). Rethinking generations. Research in Human Development, 4(3-4), 219-370.

Asmafiliz, E. ve Şalvarcı Türeli, N. (2018). Y kuşağı bireylerin sosyal medya kullanım sıklığı üzerine amprik bir araştırma, 5th International Conference on Social Sciences and Education Research, Bildiriler Kitabi, içinde (294-312).

Ayçiçek, İ. M. (1994). Kuşaklararası çatışma. Augsburg,Germany:PresseDruck.

Aydemir, M. ve Dinç, M. S. (2015). İş ve yaşam dengesi arayışında kuşak farklılıklarının ve kuşakların iş değerlerinin etkisi üzerine bir model çalışması, 23. Ulusal Yönetim ve Organizasyon Kongresi, Bildiri Kitabı, içinde (867-873).

Bayramoğlu, G ve Şahin, M. (2017). Field study investigating the expectations of employment and tendencies of the generations Y. Journal of Labour Relations, 8(2), 56-75.

Berkup, S. B. (2014). Working with generations $X$ and $Y$ in generation $Z$ period: Management of different generations in business life. Mediterranean Journal of Social Sciences, 5 (19), 218-229.

Biggs, S. (2007). Thinking about generations: Conceptual positions and policy implications. Journal of Social Issues, 63(4), 695-711.

Börü, D. E. Ve Yurtkoru, E. S. (2016). Yeni kuşakların iş yaşamı tarzları üzerine ölçek geliştirme çalışması. Adana Çukurova Üniversitesi IV. Örgütsel Davranış Kongresi, Bildiriler Kitabı, içinde (64-68).

Büyüköztürk, Ş. (2002). Sosyal bilimler için veri analizi kitabı: İstatistik araştırma deseni SPSS uygulamaları ve yorum. Ankara: Pegem A.

Can, A. (2013). SPSS ile bilimsel araştırma sürecinde nitel veri analizi. Ankara: Pegem Akademi.

Census (2006). Selected characteristics of baby boomers 42 to 60 years old in 2006. Chicago: US Census Bureau.

Comte, A. (1974). The positive philosophy. with an introduction by A. S. Blumberg (originally published 1855), New York: AMS Press.

Çetin-Aydın, G. ve Başol, O. (2014). X ve Y kuşağı: Çalışmanın anlamında bir değişme var mı?, EJOVOC (Electronic Journal of Vocational Colleges), 4 (4), 1-15. http://dx.doi.org/10.17339/ejovoc.41369 
Demirkaya, H., Akdemir, A., Karaman, E. ve Atan, Ö. (2015). Kuşakların yönetim politikası beklentilerinin araştırılması, İşletme Araştırmalarn Dergisi, 7(1), 196-204.

Dewanti, P. ve Indrajit, R.E. (2018). The effect of XYZ generation characteristics to e-commerce C-to-C: A review, Ikraith-Informatika, 2 (2), 56-60.

Dyke M. V., Haynes, C. ve Ferguson, M. (2007). Bridging the divide: A public relations perspective on intergenerational communication. Public Relations Quarterly, 52, 4, 19-23.

Ekşili, N. ve Antalyalı, Ö.L. (2017). Türkiye'de Y kuşağı özelliklerini belirlemeye yönelik bir çalışma: Okul yöneticileri üzerine bir araştırma, Humanities Sciences (NWSAHS), 12(3), 90-111, http://dx.doi.org/10.12739/NWSA.2017.12.3.4C0219

Engizek, N. ve Şekerkaya, A. (2016). X ve Y kuşağı kadınlarının karar verme tarzları bakımından incelenmesi, Mustafa Kemal Üniversitesi Sosyal Bilimler Enstitüsü Dergisi, 13 (36), 242-271.

Erdal, M. (2018). Personel bulma ve seçme süreçlerinde sosyal medya ağlarmm rolü: X ve Y kuşakları açısından bir inceleme. Yayımlanmamış Yüksek Lisans Tezi, Gazi Üniversitesi, Ankara.

Gravett, L. (2007). Bridging the generation gap how to get radio babies, boomers, gen Xers, and gen Yers to work together and achieve more. New Jersey: Career Press Inc.

Hofstede, G. (1984). Culture's consequences: Comparing values behaviors, institutions and organizations across nations (Abridged). London: Sage Publications.

Hung, K. H., Gu, F. F. ve Yim, C. K. B. (2007). A social institutional approach to 1dentifying generation cohorts in China with a comparison with American consumers, Journal of international business studies, 38 (5), 836-853.

Inglehart, R. (2008). Changing values among western publics from 1970 to 2006. West European Politics, 31(1-2), 130-146.

İnce, F. (2018). Z kuşağının girişimcilik eğilimi: Üniversite öğrencileri üzerinde bir araştırma. Pamukkale Üniversitesi Sosyal Bilimler Enstitüsü Dergisi, 32, 105-113. 
Johnson, M. ve Johnson, L. (2010). Generations Inc.: From boomers to linksters managing the friction between generations at work. New York: Amacom.

Kel, G., İlic, D. ve Yalçın, B. (2017). Y jenerasyonunun farklılaşan iş değerleri ve liderlik algılamaları. Journal of Yaşar University, 12(46), 136160.

Kuyucu, M. (2017). Y kuşağ1 ve teknoloji: Y kuşağının iletişim teknolojilerini kullanım alışkanlıkları. Gümüşhane Üniversitesi İletişim Fakültesi Elektronik Dergisi, 5(2), 845-872.

Latif, H. ve Serbest, S. (2014). Türkiye'de 2000 kuşağ ve çalışma anlayışı. Gençlik Araştırmaları Dergisi, 2 (4), 132-163.

Lower, J. (2008). Brace yourself here comes generation Y. Critical Care Nurse, 28 (5), 80-85.

Macky, K., Gardner, D. ve Forsthy, S. (2008). Generational differences at work: Introduction and overview. Journal of Managerial Psychology, 23 (8), 857-861.

Mannheim, K. (1950). Freedom, power, and democratic planning. New York: Oxford University Press. 20.03.2019 tarihinde https://archive.org/details/freedompowerdemo00mannrich adresinden erişilmiştir.

Mannheim, K. (1952). The problem of generations. In P. Kecskemeti (Ed.) Essays on the sociology of knowledge. (pp. 276-320). London: Routledge \& Kegan Paul.

Martin, C. A. ve Tulgan, B. (2002). Managing the generation mix: From collision to collaboration. Massachusetts: Human Resource Development Press.

McCrindle, M. ve Wolfinger, E. (2010). Generations defined. Ethos, 18 (1) 8-13.

Morsümbül, Ş. (2014). Kültürel değerlerin üç kuşak arasındaki değişimi üzerine bir inceleme: Ankara örneği, Hacettepe Üniversitesi Türkiyat Araştırmaları Dergisi, 21, 137-160.

Mücevher, M.H. (2015). X ve Y kuşă̆ının birbirlerine karşı özellik ve etkileşim algıları: SDÜ örneğgi. Yayımlanmamış Yüksek Lisans Tezi, Süleyman Demirel Üniversitesi, Isparta. 
Onurlubaş, E. ve Öztürk, D.(2018). Sosyal medya uygulamalarının Y kuşağ1 satın alma davranışı üzerine etkisi: Instagram örneği. OPUSUluslararası Toplum Araştırmaları Dergisi, 9(16), 984-1016. http://dx.doi.org/10.26466/opus.471771

Özdemir, Ş. (2017). Kuşaklar teorisine göre Türkiye'deki gençlerin medya kullanım alışkanlıkları ve İstanbul örneği, Yayımlanmamış Yüksek Lisans Tezi, Marmara Üniversitesi, İstanbul.

Pecchioni L. L., Wright K. B. ve Nussbaum J. F. (2005). Life span communication. LEA: Mahwah, New Jersey.

Rokeach, M. (1973). The nature of human values. New York: Free Press.

Rokeach, M., \& Ball-Rokeach, S. J. (1989). Stability and change in American value priorities, 1968-1981. American Psychologist, 44(5), 775-784. http://dx.doi.org/10.1037/0003-066X.44.5.775

Sağır, A. ve Eraslan, H.(2019). Akıllı telefonların gençlerin gündelik hayatlarına etkisi: Türkiye'de üniversite gençliği örneği. OPUS-Uluslararası Toplum Araştırmaları Dergisi,10(17),48-78.

http://dx.doi.org/10.26466/opus.515339

Sarıtaş, E. ve Barutçu, S. (2016). Tüketici davranışlarının analizinde kuşaklar: Sosyal medya kullanımı üzerinde bir araştırma. Pamukkale Journal of Eurasian SocioEconomic Studies (PJESS), 3(2), 1-15.

Schwartz, S. H. (2006). A theory of cultural value orientations: Explication and applications, Comparative Sociology, 5(2-3), 137-182.

Sipahi, B., Yurtkoru, E.S. ve Çinko, M. (2008). Sosyal bilimlerde SPSS'le veri analizi. (2. bsm). İstanbul: Beta.

Strauss, W. ve Howe, N. (1991). In Generations: The history of America's future, (p.1584-2089). Quill William Morrow, New York.

Süer, S., Sezgin, K. ve Oral, B. (2017). Z kuşağındaki öğrencilerin internete ilişkin algılarının belirlenmesi: Bir metafor çalışması, Elektronik Eğitim Bilimleri Dergisi, 6(12), 190-203.

Şimşeker, M. (2005). Sekizinci sını öğrencilerinin matematik öğretmenlerinin kişilerarası davranış özelliklerini algılamaları. Yayımlanmamış Yüksek Lisans Tezi, Orta Doğu Teknik Üniversitesi, Ankara.

Taş, H.Y., Demirdöğmez, M. ve Küçükoğlu, M. (2017). Geleceğin mimarları Z kuşağının iş hayatına muhtemel etkileri. OPUS-Uluslararası Toplum Araştırmaları Dergisi, 7 (13), 1031-1048. 
Tolbize, A. (2008). Generational differences in the workplace. Research and Training Center on Community Living: University of Minnesota. https://rtc.umn.edu/docs/2 18 Gen diff workplace. pdf

Toruntay, H. (2011). Takım rolleri çalışması: X ve Y kuşağı üzerinde karşılaştırmalı bir araştırma. Yayımlanmamış Yüksek Lisans Tezi, İstanbul Üniversitesi, İstanbul.

Tutgun-Ünal, A. (2013). Nesiller ayrilıyor: X, Y ve Z nesilleri. Açıbbilim, 18.09.2018 tarihinde http://www.acikbilim.com/2013/09/ dosyalar Lnesiller-ayriliyor-x-y-ve-z-nesilleri.html adresinden edinilmiştir.

Tutgun-Ünal, A. (2015). Sosyal medya bağımlılı̆̆ı: Üniversite öğrencileri üzerine bir araştırma. Yayımlanmamış Doktora Tezi, Marmara Üniversitesi, İstanbul.

Tutgun-Ünal, A. ve Soykan, C. (2015). A comparative study of social network usage purpose and frequency among generations, 9. Uluslararası Bilgisayar ve Öğretim Teknolojileri Sempozyumu, Afyon.

Türk, A., (2013). Y kuşağı. İstanbul: Kafekültür Yayıncılık.

TÜIK (2018). Temel istatistikler/ Nüfus ve demografil Nüfus projeksiyonlarl Yaş grubu ve cinsiyete göre nüfus. Türkiye İstatistik Kurumu, http://www.tuik.gov.tr/UstMenu.do?metod=temelist adresinden 24.02.2019 tarihinde ulaşılmıştır.

Williams, A. (2001) Intergenerational communication across the lifespan, LEA: Mahwah, New Jersey.

Williams, A. ve Harwood, J. (2008). Intergenerational communication: Intergroup, accomodation, and family perspectives.In (J F. Nussbaum, ed.) Handbook of Communication and Aging Research, LEA, London, (p.115-137).

Yıldırım Becerikli, S. (2013). Kuşaklararası iletişim farklılığı: Bilim teknoloji ve yenilik haberleri üzerinden bir odak grup çalışması. Selçuk İletişim, 8 (1), 5-18.

Yiğit, Z. (2010). X ve Y kuşaklarının örgütsel tutumlar açısından incelenmesi ve bir örnek olay. Yayımlanmamış Yüksek Lisans Tezi, Bahçeşehir Üniversitesi, İstanbul.

Zemke, R., Raines, C., ve Filipczak, B. (2013). Generations at work: Managing the clash of boomers, gen Xers, and gen Yers in the workplace, (2nd Ed.). USA: Amacom. 


\section{Kaynakça Bilgisi / Citation Information}

Deniz, L. ve Tutgun Ünal, A. (2019). Sosyal medya çağında kuşakların sosyal medya kullanımı ve değerlerine yönelik bir dizi ölçek geliştirme çalışması. OPUS-Uluslararası Toplum Araştırmaları Dergisi, 11(18), 1025-1057. DOI: 10.26466/opus.557240 